\title{
Continuity of Procambium and Anomalous Cambium During Formation of Successive Cambia in Celosia argentea
}

\author{
Elżbieta Myśkow ${ }^{1}$ D $\cdot$ Edyta M. Gola $^{1}$ (D) Mirela Tulik ${ }^{2}$
}

Received: 30 October 2018 / Accepted: 11 February 2019 / Published online: 23 March 2019

(c) The Author(s) 2019

\begin{abstract}
The development of woody plants is related to the continuity of the procambium and cambium. Whether such a continuity is present in plants with successive cambia, especially in those, where the first cambium is formed outside the primary vascular bundles, has not been analyzed so far. Therefore, we studied the development of vascular meristem in Celosia argentea, in which the first and successive cambial cylinders arise outside the primary bundles and, intriguingly, in the literature are interpreted as developmentally independent structures. Our results showed that in C. argentea, the outermost procambial cells maintain their meristematic characteristics during differentiation of vascular bundles and divide periclinally, forming the zone of procambium-derived cells outside the primary bundles. This zone comprises parenchyma cells bordering the bundles, and a continuous ring of the incipient cambial cells neighboring the primary cortex. Later in the development, the ability to preserve the outermost cells in the cambium undifferentiated is repeated during the formation of successive cylinders of cambia. Together, our results clearly point to the developmental continuity of the procambium and successive cambia in $C$. argentea, despite their seemingly spatial distinctiveness. We postulate that the mechanism demonstrated in $C$. argentea is universal and orchestrates the development of successive cambia in other plant species.
\end{abstract}

Keywords Amaranthaceae $\cdot$ Celosia $\cdot$ Procambium-cambium transition $\cdot$ Successive cambia

\section{Introduction}

The formation of the secondary vascular tissues is a polyphyletic feature gained by different groups of plants, and related to their type of growth form, such as shrubs, trees and lianas (Rowe and Speck 2005; Lens et al. 2013). As an evolutionary achievement, this feature is crucial for longevity of a plant and, in addition, enables colonization of new ecological niches (Rowe and Speck 2005). The meristem responsible for the secondary growth is a vascular cambium. The typical cambium is a structure composed of a

Elżbieta Myśkow and Edyta M. Gola contributed equally to this work.

Elżbieta Myśkow

elzbieta.myskow@uwr.edu.pl

1 Institute of Experimental Biology, University of Wrocław, Kanonia 6/8, 50-328 Wrocław, Poland

2 Department of Forest Botany, Faculty of Forestry, Warsaw University of Life Sciences, Nowoursynowska 159, 02-776 Warsaw, Poland single continuous cylinder of cambial meristematic cells. As a consequence of periclinal divisions of the cambial cells the secondary conductive tissues are established: secondary xylem to the inside and secondary phloem to the outside of the stem, branches and roots (Iqbal and Ghouse 1990; Larson 1994).

The primary growth and formation of conductive tissues are achieved due to the activity of a primary vascular meristem, the procambium. The developmental transition to the secondary type of growth is accomplished by the emergence of a continuous cylinder of cambium. In majority of plants with typical secondary growth, procambium and its derived primary tissues form discrete vascular bundles in stems. Differentiation of the procambium into primary conductive tissues starts from the outermost (protophloem) and innermost (protoxylem) cells, and continues towards to the center of the bundle. Some procambial cells, in the very middle of the bundle (between metaxylem and metaphloem), remain undifferentiated and are the founder cells for the fascicular cambium (Larson 1994; Růžička et al. 2015), which ensures developmental and functional continuity of both vascular meristems (Soh 1972; Myśkow 2010; Spicer and 
Groover 2010). To establish a continuous cylinder of cambium, parenchyma cells, located between vascular bundles, transdifferentiate and form the interfascicular cambium. The typical continuous cylinder of cambium, once formed, is a permanent structure, which throughout the entire life of a plant produces secondary vascular tissues (Larson 1994; Spicer and Groover 2010).

Apart from the typical pattern of cambium formation, several anomalous cambia differing in their location, development and functioning are known in plants. Their activity is related to the formation of, for example, reticulate or furrowed secondary tissues, inclusions of phloem or xylem, reverse polarity of vascular tissues as well as formation of monkey ladder vines (Carlquist 1988, 1991; IAWA Committee 1989; Philipson 1990; Araújo and Costa 2006; Schweingruber et al. 2008; Spicer and Groover 2010; Terrazas et al. 2011; Angyalossy et al. 2012; Rajput et al. 2013, 2018; Fisher and Blanco 2014). The variety of anomalous cambia results in modified mechanical and conductive properties, increasing diversity of growth forms and demonstrating adaptive potential of plants (Rowe and Speck 2005).

An interesting example of anomalous secondary growth is the activity of several cylinders of meristematic cells, so-called successive cambia (Balfour 1965; Bailey 1980; Fahn and Zimmermann 1982; Carlquist 1988; Rajput et al. 2010; Heklau et al. 2012). Upon development of successive cambia, the first meristematic cylinder develops either typically, from fascicular and interfascicular cambium, or is established de novo outside the primary vascular bundles, which remain discrete (Balfour 1965; Studholme and Philipson 1966; Bailey 1980; Tamaio et al. 2009; Terrazas et al. 2011; Rajput et al. 2012). The activity of the first cambium is only temporary and ceases after formation of several layers of secondary conductive tissues. The next successive cambial cylinder is established de novo externally to the already formed secondary phloem, and its divisional activity is also limited in time. The process of initiation and cessation of the activity of cambial cells repeats, resulting in the formation of several successive cambia. Each of the cambial cylinders produces its own derivative secondary vascular tissues, which are separated by parenchymatous cells, so-called the conjunctive tissue (Carlquist 2007; Heklau et al. 2012). Interestingly, in some species, the successive cylinders of the vascular tissues can be interconnected, forming a threedimensional reticulate network (Schmitz et al. 2008; Robert et al. 2011).

The successive cambia have been examined, among others, in an annual commonly grown ornamental plant Celosia argentea (Amaranthaceae). Surprisingly, the primary vascular structure has not been analyzed in this plant species; the studies focused only on development and structure of successive cambial cylinders (Balfour 1965; Rajput 2001). In these studies, the starting point for describing secondary growth in $C$. argentea was the formation of the first cylinder of cambium externally to existing vascular bundles. The first cambium has been reported to arise de novo as a continuous cylinder, without developmental relation to the primary vasculature. Its origin has been postulated to be an outcome of periclinal divisions of parenchymatous cells, located outside the primary phloem (Balfour 1965). Then, the next successive cambial cylinders have also been interpreted as arising de novo from parenchymatous cells, externally to recently formed secondary phloem. Thus, each newly formed cylinder has been considered to be developmentally independent (Rajput 2001). Interestingly, in other representatives of Amaranthaceae, as for example in Iresine analyzed in detail, successive cambia are formed from the outermost undifferentiated derivatives of the last functioning cambium. Therefore, all cambial cylinders are interpreted as one continuous meristem, active throughout the secondary plant growth (Balfour 1965). In C. argentea, each cambial cylinder is diversified into two circumferentially alternating segments: one producing conducting elements of secondary xylem and phloem, and the second segment producing secondary parenchyma cells. As a result, the secondary structure resembles the arrangement of discrete vascular bundles, distributed in parenchyma tissue (Rajput 2001).

The continuity of the primary and secondary vasculature is crucial for the uninterrupted hydraulic conductivity, and thus for the integrated functioning of the whole plant. Therefore, it was postulated that both the procambium and then cambium are one continuous meristem throughout the development (Soh 1972; Myśkow 2010; Spicer and Groover 2010). It becomes particularly interesting to clarify whether the continuity of both vascular meristems exists in a plant where the procambium is spatially separated from the first cambium, which is additionally interpreted as initiated de novo, without relation to the primary vasculature (Balfour 1965). Such analyses enable better understanding of the basic mechanisms upon the successive cambia development in a variety of unrelated species. Therefore, we analyzed in detail the development of the primary and secondary vascular meristems in Celosia argentea, which is a good model species for analyzing the structure of the successive cambia. The main aims of this work were to answer: (i) whether the primary vascular structure has an impact on the formation of the first cambial cylinder, and (ii) if the procambium and cambium are one vascular meristem, what is a mechanism sustaining its continuity upon development.

\section{Materials and Methods}

Commercially available seeds of Celosia argentea were sown to pots and grown in the phytotron in controlled conditions (16 h light $/ 8 \mathrm{~h}$ night; $30^{\circ} \mathrm{C} ; 70 \%$ humidity). For the 
developmental analyses, 20 plants were sampled before the flowering and ten after flowering, reaching at least $25 \mathrm{~cm}$ in height. Each plant was cut into smaller pieces, and fixed separately in a mixture of formalin-acetic acid-alcohol (FAA) for a week. Then, the material was rinsed in 50\% ethanol, dehydrated in a graded ethanol-tertiary butanol series (from 50 to $96 \%$, and three changes in $100 \%$ butanol, in each change for $1.5 \mathrm{~h}$ ), transferred to a graded series of tertiary butanol-paraffin mixtures (containing from 20 to $80 \%$ paraffin, in each change for $1.5-2 \mathrm{~h}$ ), and embedded in paraffin (three changes in pure paraffin, the last one left overnight; Ruzin 1999). Each plant (divided into smaller fragments as mentioned above) was then sectioned transversely ( 20 plants) or longitudinally (10 plants). The apical parts of each plant, $1.5-2 \mathrm{~cm}$ long, were cut into the series of 5-8- $\mu \mathrm{m}$-thick sections in purpose to show the changes in the vascular structure during development, from the procambium to the first cambium. Such developmental series were prepared on a Leica RM 2135 rotary microtome (Leica Instruments $\mathrm{GmbH}$, Wetzlar, Germany), double stained with Alcian blue-Safranin O, and mounted in Euparal (Ruzin 1999). The entire series of the transverse and longitudinal sections were then analyzed and documented in a brightfield microscope.

To identify the youngest primary phloem elements, we applied the protocol of detection of callose deposited in sieve plates and thus being the marker for the phloem. Five additional shoot apices of plants before flowering were cut longitudinally and stained with $1 \%$ aniline blue solution in $0.1 \mathrm{M}$ phosphate-buffered saline, pH 9 (PBS; Ruzin 1999). The fluorescent signal for callose was detected under an epi-fluorescent microscope using UV excitation light (360-370 nm).
All analyses were performed under the microscope (Olympus BX50) cooperating with an Olympus DP71 camera and Cell^B software (Olympus Optical Co., Warsaw, Poland). CorelDRAW 2017 (Corel Corporation, USA) was used for processing the images and preparation of figures.

Throughout the text, we use the term "successive cambium" according to the definition given by Carlquist (2007), by which the subsequent cylinders of secondary vascular tissues are separated by the parenchymatous or fibrous conjunctive tissue. The term "anomalous cambia" is broader in its meaning and refers to different types of atypical growth.

\section{Results}

The primary structure of Celosia argentea stems, analyzed at the cross-Sect. $0.5-0.6 \mathrm{~cm}$ below the shoot apex, was typical of dicotyledonous plants. Stems were covered with an epidermis, and contained a primary cortex and collateral vascular bundles arranged in a ring surrounding a parenchymatous pith (Fig. 1a-b). In terms of the secondary growth, the first cylinder of anomalous cambium, located outside the primary bundles, was clearly visible from 2.5 to $3.5 \mathrm{~cm}$ below the shoot apex (Fig. 1c). In older stems, ca. $25-30 \mathrm{~cm}$ below the apex, several cylinders of successive cambia with secondary vascular tissues, separated by the conjunctive tissue, were visible (Fig. 1d).

The development of the shoot vasculature was analyzed on the series of transverse and longitudinal sections (Fig. 2). The discrete strands of procambium were distinct approximately $70 \mu \mathrm{m}$ below the shoot apex (Fig. 2a-e). Procambium cells divided periclinically (Fig. 2c, divisions pointed
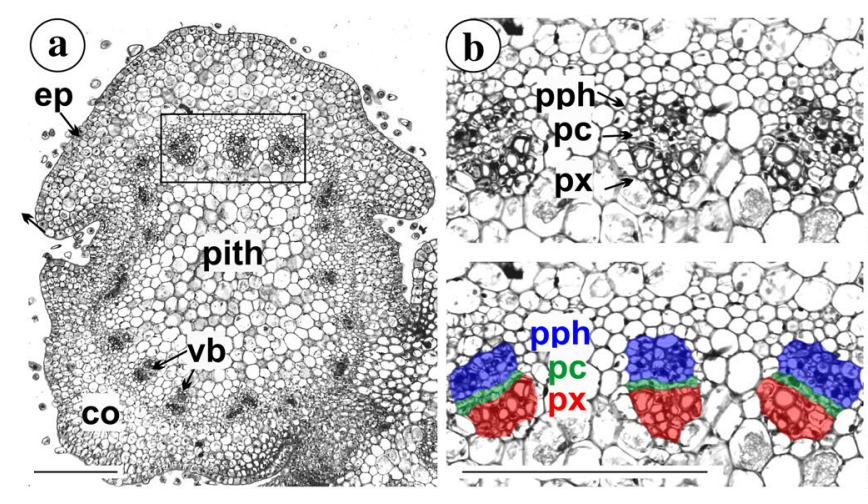

Fig. 1 General structure of the Celosia argentea shoots at the crosssections, presenting different stages of vasculature development. a the arrangement of the discrete vascular bundles in a ring, and b the structure of the primary bundles outlined by the rectangle in (a) - the upper panel, and the interpretation of these vascular bundles (the lower panel), with different colors used to facilitate tissue recognition: procambium filled with green, primary phloem with blue, and primary xylem with red; the same colors are used in all figures; c the first cylinder of the successive cambium with derived second-
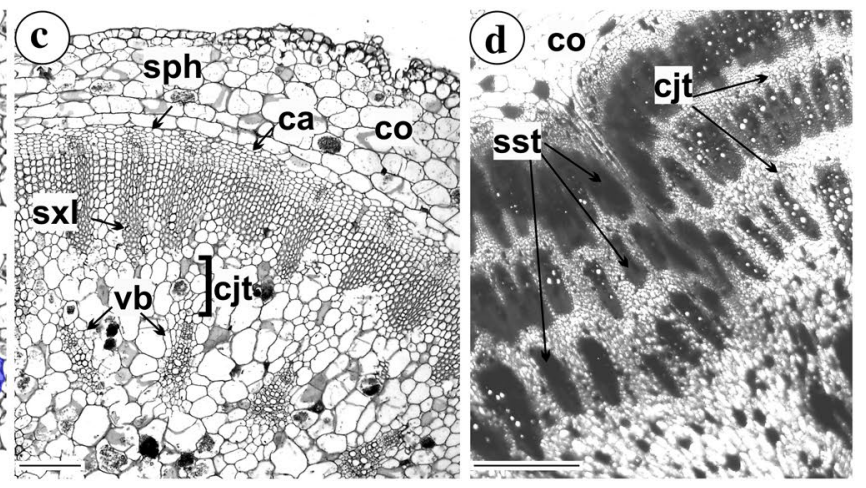

ary tissues separated from the primary vascular bundles by the conjunctive tissue; $\mathbf{d}$ the secondary structure of the $C$. argentea shoots with three successive cylinders of secondary tissues separated by the conjunctive tissue. $c a$ cambium, $c j$ conjunctive tissue, $c o$ cortex, $e p$ epidermis, $p c$ procambium, $p p h$ protophloem, $p x$ protoxylem, $s p h$ secondary phloem, sst successive cylinders of secondary tissues, $s x l$ secondary xylem, $v b$ vascular bundle. Scale bars $\mathbf{a}-\mathbf{c}-200 \mu \mathrm{m}, \mathbf{d}-$ $1000 \mu \mathrm{m}$. (Color figure online) 

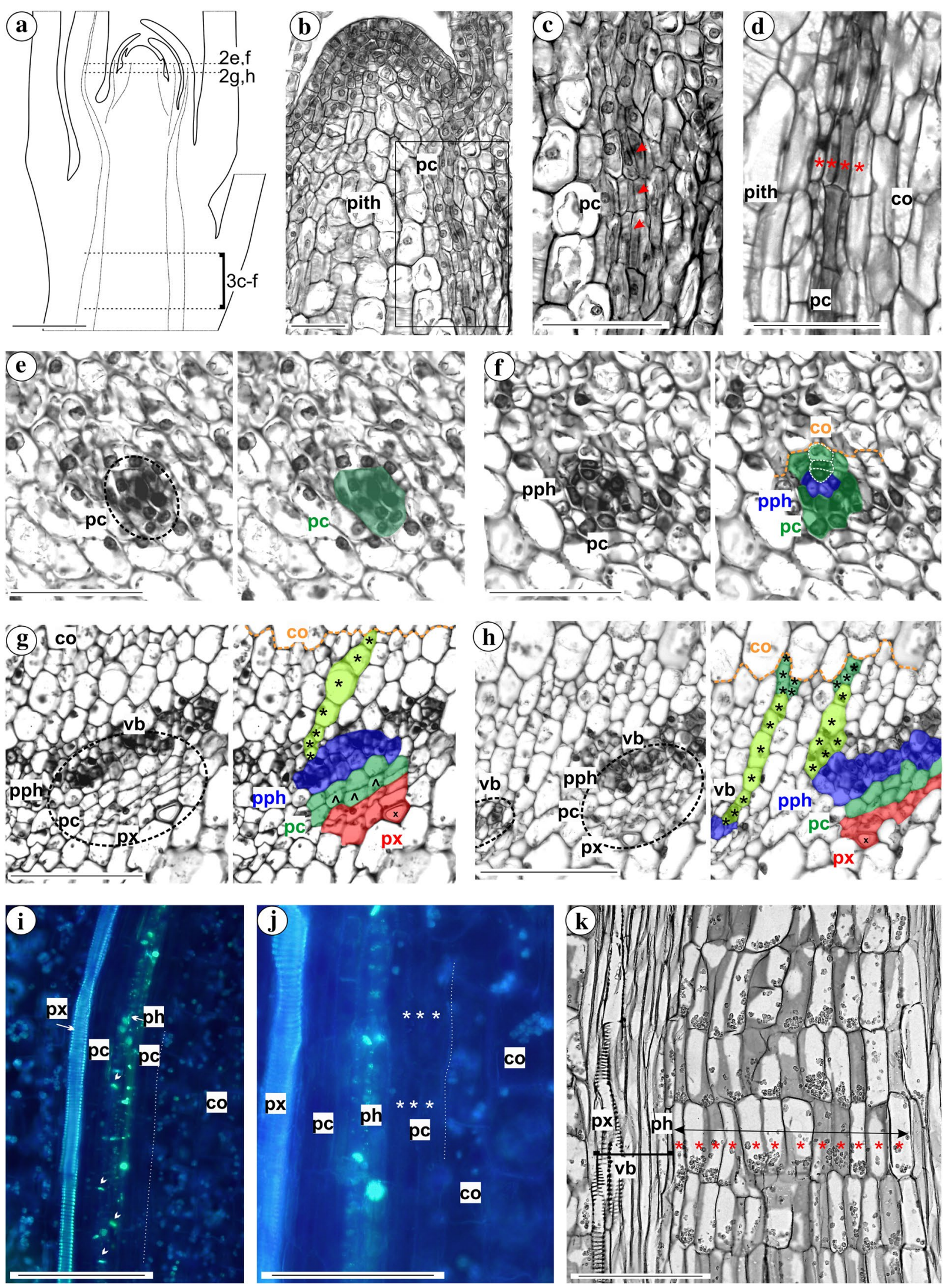
4Fig. 2 The structure of the primary vasculature and formation of the procambium-derived zone in Celosia argentea shoots, shown at longitudinal median sections (a-d, $\mathbf{i}-\mathbf{j})$, longitudinal radial sections $(\mathbf{k})$ and transverse sections (e-h). a The schematic representation of $C$. argentea shoot showing the subsequent stages of the vascular system development in relation to the distance from the shoot apex. Dashed lines show the level of sectioning, and the labels (2e,f; $2 \mathrm{~g}, \mathrm{~h}$ and $3 \mathrm{c}-\mathrm{f})$ refer to the corresponding Figs. $2 \mathrm{e}-\mathrm{h}$ and $3 \mathrm{c}-\mathrm{f}$, b-shoot apical meristem and developing procambial strands; $\mathbf{c}$-close-up of the procambium delineated in (b) by the rectangle, periclinal divisions of the procambial cells are pointed with red arrows; $\mathbf{d - r a d i a l}$ rows of cells of common origin (an exemplary row labeled with red asterisks) formed by repeated periclinal divisions of procambial cells; $\mathbf{e}-\mathbf{h}-$ development of the same vascular bundle (left panels), and the interpretation of the vascular tissues at corresponding images (right panels); e-procambial cells form a discrete vascular bundle (encircled at left, and filled with dark green at right); f-differentiation of the first protophloem sieve tubes (filled with blue), cells located outwards the protophloem remain undifferentiated (filled with dark green) and divide periclinally (an exemplary row of cells outlined with the white dashed line); note that in this way, two pools of procambial cells located at both sides of protophloem are formed; the orange dashed line indicates the border between the cortex and the vascular bundle; $\mathbf{g}$ - further development of the vascular bundle (encircled at left); procambial cells (labelled with dark green) are typically located between the primary phloem (filled with blue) and primary xylem (filled with red) and divide periclinally (divisions pointed with arrowheads), increasing the size of the vascular bundle; the first vessel element of protoxylem (labelled by $x$ ) differentiates at the innermost margin of the bundle; at the opposite margin, outside the primary phloem, the procambium-derived zone is formed by periclinal divisions of the outermost procambial cells (an exemplary row of cells of common origin is labelled with asterisks and filled with yellow-green color); $\mathbf{h}$-within the procambium-derived zone (exemplary rows of the cells of common origin are marked with asterisks), two parts are distinguishable: one, composed of small cells of the incipient cambial founders (cells filled with dark green and located at the contact with the cortex), and the other one, composed of parenchymatous cells located inside, above the primary phloem (filled with yellowgreen color); $\mathbf{i}-\mathbf{j}$ - visualization of the primary tissue arrangement by the detection of callose in the sieve plates (white arrowheads) of protophloem elements, and autofluorescence of the secondary cell walls of protoxylem vessels viewed under UV light. Two pools of procambial cells are distinct: the first one typically located between protoxylem and protophloem, and the second one, outermost of the primary phloem. The border between the cortex and the procambium-derived zone is denoted by the dashed line; $\mathbf{j}$-the cells of common origin (labelled with asterisks) form distinct radial rows in the procambiumderived zone between the primary phloem and the cortex (dashed line); $\mathbf{k}$ - the procambium-derived zone increases due to repeated periclinal divisions, forming distinct rows of the cells of the common origin (labelled with asterisks, and by the double-sided arrow) outside the primary phloem. co cortex, $p c$ procambium, $p h$ primary phloem, $p p h$ protophloem, $p x$ primary xylem, $v b$ vascular bundle; Scale bars $\mathbf{a}, \mathbf{b}-200 \mu \mathrm{m}, \mathbf{c}-\mathbf{h}, \mathbf{j}-50 \mu \mathrm{m}, \mathbf{i}-100 \mu \mathrm{m}, \mathbf{k}-200 \mu \mathrm{m}$. (Color figure online)

with arrows), forming rows of 2-4 radially arranged cells of common origin (Fig. 2d, cells labeled with asterisks). The first procambial derivatives differentiated as the sieve tubes of protophloem in the distance of approximately $120 \mu \mathrm{m}$ below the apex (Fig. 2a, f, protophloem tubes are filled with blue). The protophloem elements did not differentiate at the outermost margin of the procambial bundle because outwards to the maturing protophloem sieve tubes some procambial cells remained undifferentiated (Fig. 2f, dark green cells neighboring the cortex). In consequence, two pools of the procambial meristematic cells were distinguishable, namely (1) one typically located in the center of the bundle (between protophloem and protoxylem elements), and (2) the other one in an atypical position, outermost to differentiated protophloem elements (Fig. 2f, g, dark green cells). During further development, at the innermost margin of the vascular bundle, the protoxylem cells differentiated (Fig. 2a, $\mathrm{g}$; cells filled with red) at approximately $170 \mu \mathrm{m}$ below the apex. The procambial cells in the center of the bundle (the first pool of the procambial cells) divided periclinally (Fig. 2g, arrowheads), increasing the size of the vascular bundle, and then differentiating into successive primary xylem and phloem elements.

The second pool of the procambial cells, at the outermost margin of the vascular bundle, (Fig. 2f, the outermost dark green cells) started the periclinal divisions giving rise to the radial rows of the cells of common origin (Fig. 2f, cells outlined with a white dashline). These procambium-derived cells formed a distinct zone between the primary vascular bundles (its primary phloem) and the cortex (Fig. 2g, h, exemplary rows of the cells of common origin are filled with yellow-green color and labeled with asterisks). The presence of the meristematic cells outwards to the mature protophloem was further confirmed with the use of the detection of callose, which is normally deposited in the pores of the sieve plates (Fig. 2i, j). On the longitudinal sections, the innermost protoxylem elements were identified due to autofluorescence of the secondary cell walls of the vessels, and protophloem sieve tubes were visualized by the fluorescent signal of stained callose. In addition, two pools of meristematic cells were recognized as the cells lacking fluorescence, i.e., typical procambial cells between differentiated vascular elements (the first pool of procambial cells), and the outermost procambial cells (the second pool), located between the differentiated protophloem elements and the cortex (Fig. 2i, j). The outermost procambial cells repeatedly divided periclinally (Fig. 2j, cells marked with asterisks), producing radial files of the cells of the procambiumderived zone, shown on the transverse sections (Fig. 2g, h, yellow-green colored cells). The common origin of the cells, forming rows in this zone, was also evident at the radial longitudinal sections, where these cells had the same lengths and formed distinct tiers (Fig. 2k).

During the further development of the procambiumderived zone, its outermost cells started to divide in all directions, forming numerous small cells (Fig. 2a, h, dark green cells, located in the vicinity of the cortex). Initially, the smaller cells became apparent five-six cells above the primary bundles (Fig. $2 \mathrm{~h}$ ), then the divisions spread around 

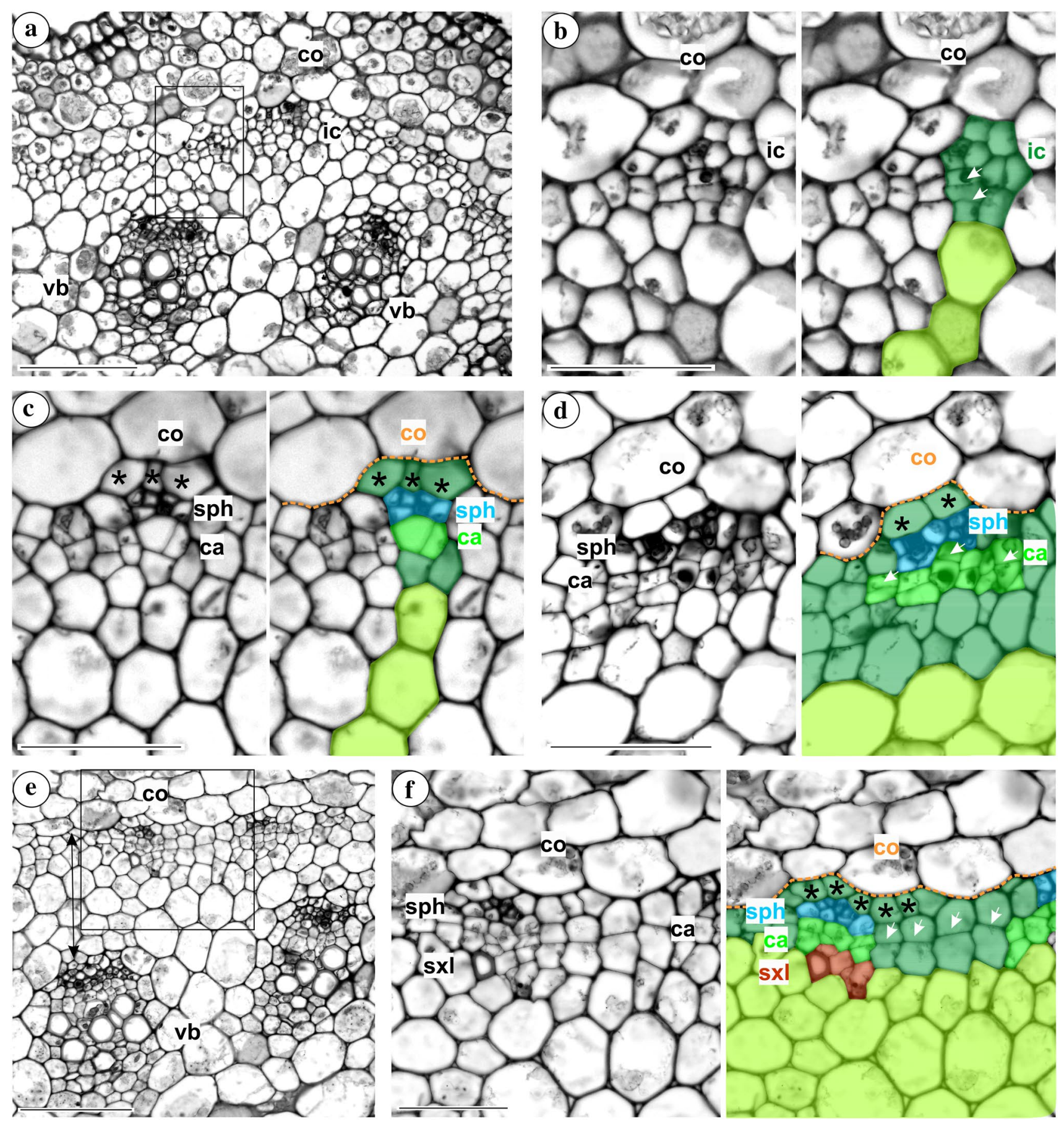

the whole stem circumference leading to the emergence of the continuous ring of smaller cells (Fig. 3a, smaller cells labeled with ic). Consequently, two parts were distinguished in the procambium-derived zone between the primary phloem and the cortex: an external part, 2-4-cell thick, with small undifferentiated cells, and an internal part, 4-6-cell thick, with parenchymatous cells (Figs. 2h, 3a and b, smaller cells filled with dark green, parenchymatous cells with yellow-green color).
The small undifferentiated cells in the external part of the procambium-derived zone (Fig. 2h, dark green colored cells) became the founders of the first cylinder of anomalous cambium, whereas the parenchymatous cells will give rise to the conjunctive tissue, separating the arising cambium from the primary vascular bundles (Fig. 1c). The first cambial cells emerged in separate locations above the primary bundles and were identified based on periclinal divisions (Fig. 3a, $\mathrm{b}$, divisions pointed by arrows). The repeated divisions of the cambial cells increased the width of the entire cambial 
4Fig. 3 Development and activity of the first cylinder of the successive cambium presented at the transverse sections through the representative shoot. a general structure of the stem during initiation of the first cambium within the procambium-derived zone, which is distinct above the primary bundles; b-d, f cambium development, presented at the cross-sections (left panels) and the interpretation of the process (corresponding right panels); b magnification of the region delineated by the rectangle at (a); within the procambium-derived zone, two types of cells are distinct: parenchymatous cells (exemplary cells of common origin are filled with yellow-green) and smaller, undifferentiated cells (ic, filled with dark green; note their common origin with the parenchymatous cells) located below the primary cortex; the latter start dividing periclinally (white arrows) and are the incipient cambial cells; c within the pool of the incipient cambium cells (ic, dark green cells), the first elements of the secondary phloem (filled with blue) differentiates, however, not in the direct contact with the cortex - the outermost cells remain undifferentiated (filled with dark green and marked with asterisks); inwards, below the secondary phloem the cambial cells (ca) can be recognized; $\mathbf{d}$ cambial cells divide periclinally (white arrows) increasing the size of the cambial zone; outside the cambial cylinder, several cells remain undifferentiated (filled with dark green and labeled with asterisks); e general structure of the stem with the established first cambium, and $\mathbf{f}$ magnification of the region delineated by the rectangle at (e); the first secondary xylem elements (cells filled with red) differentiate at the innermost side of the cambial cylinder; periclinal divisions (white arrows) spread circumferentially, leading to the formation of the continuous cambial cylinder; the outermost cells at the margin of the cambial cylinder remain undifferentiated (marked with asterisks). $\mathrm{ca}$ cambium, co cortex, ic incipient cambium, sph secondary phloem, $s x l$ secondary xylem, $v b$ vascular bundle; Scale bars $\mathbf{a}, \mathbf{e}-100 \mu \mathrm{m}, \mathbf{b}-\mathbf{d}$, f $-50 \mu \mathrm{m}$. (Color figure online)

meristematic zone (Fig. 3d, divisions pointed with white arrows). Then, the external cambial derivatives (but not the ones in direct contact with the cortex) differentiated as the secondary phloem elements (Fig. 3c, d, secondary phloem elements labeled with blue). After formation of several secondary phloem cells, the secondary xylem developed at the opposite side of the meristematic zone (Fig. 3e, f, secondary xylem filled with red). Concomitantly with differentiation of the secondary vascular elements, the cells neighboring the cambium started to divide periclinally (Fig. 3f, white arrows), establishing the first continuous cylinder of the anomalous cambium. Its further activity gave rise to the secondary vascular tissues (Fig. 1c).

Notably, some outermost cells in the cambial meristematic zone again remained undifferentiated (Fig. 3c, d, $\mathrm{f}$, cells marked with asterisks). The maintenance of their meristematic characteristics was the starting point for the formation of the next successive cambium.

\section{Discussion}

The formation of successive cambia is a well-known phenomenon in Celosia (Balfour 1965; Rajput 2001). According to the literature, the first cylinder of cambium in this genus is formed de novo in an atypical location outside the primary phloem, by divisions of the parenchyma cells (Balfour 1965). Thus, in contrast to the majority of woody plants where the procambium contributes to the typical cambium origination (Larson 1994; Spicer and Groover 2010; Růžička et al. 2015), in Celosia, the cambium was interpreted as not related to the primary vasculature (Balfour 1965). Bearing in mind that the procambium and cambium are one developmental continuum (Soh 1972; Myśkow 2010), it seems puzzling whether such a lack of the continuity is indeed the case in Celosia argentea. Our results contradict the previous interpretation of Celosia development as we proved that from the procambial stage throughout the formation of successive cambia, the vascular meristem is one developmental continuum. Furthermore, we showed that the outermost procambial cells preserve their undifferentiated status and the ability to divide during the maturation of the protophloem elements and further development of the vascular bundle. Concomitantly, after several rounds of mostly periclinal divisions, these cells form a distinct zone of procambiumderived cells, which includes the incipient cambial cells. The developmental continuity of the procambium and the first cylinder of cambium in $C$. argentea is visualized by distinct rows (in the cross section) or tiers (in the radial longitudinal view) of the cells between the primary bundles and the cortex. Their lineage-dependent arrangement clearly confirms a common origin with the procambial cells.

Importantly, we showed that during differentiation of the secondary vascular tissues in $C$. argentea, the outermost cambial cells again remain undifferentiated and thus are the founders for the second cylinder of cambium. This result is in line with the previous studies, in which the same phenomenon of the meristematic cell maintenance was shown in other species with successive cambia, for example in Iresine sp., Atriplex halimus, Abuta convexa, A. imene and Gallesia integrifolia (Balfour 1965; Fahn and Zimmermann 1982; Tamaio et al. 2009; Rajput et al. 2012). Our results demonstrate that the same mechanism functions earlier in the vascular meristem development and it is involved in generation of the pool of procambial-derived cells, which ultimately become the first cambial cells. This finding can be partially supported by the fact that in another species with the successive cambium, Campsis radicans, the intraxylary phloem and an internal cambium develop from undifferentiated cells at the innermost bundle margin (at the protoxylem pole) (Rajput et al. 2018).

The discovery that formation of successive cylinders of cambia relates to the residual undifferentiated cells of the previous functioning cambium (e.g. Balfour 1965; Fahn and Zimmermann 1982; Carlquist 2007 and references therein) resulted in the introduction of the term "master cambium" (Carlquist 2007). The master cambium has been defined as a pool of the meristematic cells, which become the founders for both the vascular cambium, producing secondary 
vascular tissues, and the conjunctive tissue, separating successive cylinders. Upon the establishment of the vascular cambium, the outermost cells of the master cambium are maintained as the reservoir of the cells for the consecutive new cylinders of cambia. In this part, our results on $C$. argentea are in agreement with the theory of the master cambium (Carlquist 2007). However, it is worth stressing that the master cambium was suggested to be initiated de novo from the parenchyma cells outside the primary phloem, and without developmental relation to the procambium (Carlquist 2007). In addition, in some representatives of the families Amaranthaceae, Menispermaceae and Convolvulaceae, the first successive cambium was shown to be formed de novo in the wide band of parenchyma cells, located between the cortex and the primary bundles, and interpreted as a pericycle (Fahn and Zimmermann 1982; Tamaio et al. 2009; Terrazas et al. 2011; Rajput et al. 2012, 2013). In these families, the developmental relationship between procambium and the band of parenchyma cells was not analyzed. Their common origin can be, however, inferred based on the similarity to our results on $C$. argentea, where the corresponding zone of procambium-derived cells, and in the same location, was proved to include the incipient cambial cells. Our results demonstrate that the first successive cambium in $C$. argentea is not formed de novo but its development is clearly linked with the primary growth. Therefore, for the first time, we showed the procambium-cambium continuity during the development of the successive cambia.

The emergence of the continuous cambial cylinder seems to utilize the same mechanism both in $C$. argentea and other woody plants, despite the different location of the cells involved. In $C$. argentea, the first signs of cambium emergence are visible above a particular bundle and then periclinal divisions spread circumferentially. The process of induction of divisions in the cells neighboring the cambium in Celosia resembles a normal development of the interfascicular cambium in woody plants, which arises by dedifferentiation and induced divisions of parenchymatous cells between primary bundles (Iqbal and Ghouse 1990; Larson 1994; Růžička et al. 2015). Moreover, the same mechanism of the formation of the continuous cylinder of the meristematic cells is also known during phellogen emergence, suggesting the universality of the phenomenon.

In conclusion, we showed that (1) the undifferentiated and totipotent cells derived from the procambium are preserved at the outermost margin of differentiating bundles; and (2) these meristematic cells are preserved throughout the development being the founders for the first and successive cambia formation. These findings prove (3) the presence of developmental continuum of procambium-cambium in Celosia argentea. It would be interesting to analyze in the future whether the mechanism presented here is universal and involved in formation of the successive cambia in other species, both with separate concentric cylinders (Balfour 1965; Terrazas et al. 2011; Rajput et al. 2010, 2013) and with reticulate network (Schmitz et al. 2008; Robert et al. 2011). In the latter case, the development of the connections between successive cylinders would be particularly worth analyzing.

Acknowledgements We thank our colleagues from the Department of Plant Developmental Biology, Alicja Banasiak, Alicja Dołzbłasz and Katarzyna Sokołowska for critical reading and comments on the manuscript. This study was supported by the University of Wrocław (Grant no. 0401/1068/18-2).

\section{Compliance with Ethical Standards}

Conflict of interest The authors declare no conflict of interest.

Open Access This article is distributed under the terms of the Creative Commons Attribution 4.0 International License (http://creativeco mmons.org/licenses/by/4.0/), which permits unrestricted use, distribution, and reproduction in any medium, provided you give appropriate credit to the original author(s) and the source, provide a link to the Creative Commons license, and indicate if changes were made.

\section{References}

Angyalossy V, Angeles G, Pace MR, Lima AC, Dias-Leme CL, Lohmann LG, Madero-Vega C (2012) An overview of the anatomy, development and evolution of the vascular system of lianas. Plant Ecol Divers 5:167-182. https://doi.org/10.1080/17550 874.2011.615574

Araújo GUC, Costa CG (2006) Cambial variant in the stem of Serjania orrugata (Sapindaceae). IAWA J 27:269-280. https://doi. org/10.1163/22941932-90000154

Bailey DC (1980) Anomalous growth and vegetative anatomy of Simmondsia chinensis. Am J Bot 67:147-161

Balfour E (1965) Anomalous secondary thickening in Chenopodiaceae, Nyctaginaceae and Amaranthaceae. Phytomorphology $15: 111-122$

Carlquist S (1988) Comparative wood anatomy. Systematic, ecological and evolutionary aspects of dicotyledon wood. Springer, Berlin

Carlquist S (1991) Anatomy of vine and liana stems: a review and synthesis. In: Putz FE, Mooney HA (eds) The biology of vines. Cambridge University Press, Cambridge, pp 53-71

Carlquist S (2007) Successive cambia revisited: ontogeny, histology, diversity, and functional significance. J Torrey Bot Soc 134:301-332

Fahn A, Zimmermann MH (1982) Development of the successive cambia in Atriplex halimus (Chenopodiaceae). Bot Gaz 143:353-357

Fisher JB, Blanco M (2014) A gelatinous fibers and variant secondary growth related to stem undulation and contraction in a monkey ladder vine, Bauhinia glabra (Fabaceae). Am J Bot 101:608-616. https://doi.org/10.3732/ajb.1300407

Heklau H, Gasson P, Schweingruber F, Baas P (2012) Wood anatomy of Chenopodiaceae (Amaranthaceae s.1.). IAWA J 33:205-232. https://doi.org/10.1163/22941932-90000090

IAWA Committee (1989) IAWA list of microscopic features for hardwood identification. IAWA Bull 10:219-332. https://doi. org/10.1163/22941932-90000349

Iqbal M, Ghouse AKM (1990) Cambial concept and organisation. In: Iqbal M (ed) The vascular cambium. Wiley, New York, pp 1-36 
Larson PR (1994) The vascular cambium. Development and structure. Springer, Berlin

Lens F, Davin N, Smets E, de Arco M (2013) Insular woodiness on the Canary Island: a remarkable case of convergent evolution. Int J Plant Sci 174:992-1013. https://doi.org/10.1086/670259

Myśkow E (2010) Procambium-cambium transition during vascular meristem development in. Diospyros lotus Botany 88:985-993. https://doi.org/10.1139/B10-070

Philipson WR (1990) Anomalous cambia. In: Iqbal M (ed) The vascular cambium. Wiley, New York, pp 201-212

Rajput KS (2001) Secondary growth of the stem of Celosia argentea L. and Aerva sanguinolenta (L.) Blume (Amaranthaceae). Phyton 41:169-171

Rajput KS, Patil VS, Kapadane KK (2010) Development of lateral meristem and pattern of secondary growth in stems and roots of Spinacia oleracea Linn. (Amaranthaceae). Feddes Repert 121:209-218. https://doi.org/10.1002/fedr.201000009

Rajput KS, Fiamengui MB, Marcati CR (2012) Stem anatomy and development of successive cambia in the neotropical liana Securidaca rivinifolia (Polygalaceae). IAWA J 33:391-402. https://doi. org/10.1163/22941932-90000102

Rajput KS, Patil VS, Rao KS (2013) Wood anatomy and the development of interxylary phloem of Ipomoea hederifolia Linn. (Convolvulaceae). J Plant Growth Regul 32:654-662. https://doi. org/10.1007/s00344-013-9334-8

Rajput KS, Gondaliya AD, Lekhak MM, Yadav SR (2018) Structure and ontogeny of intraxylary secondary xylem and phloem development by the internal vascular cambium in Campsis radicans (L.) Seem. (Bignoniaceae). J Plant Growth Regul 37:755-767. https://doi.org/10.1007/s00344-017-9771-x

Robert EMR, Schmitz N, Boeren I, Driessens T, Herremans K, De Mey J, Van de Casteele E, Beeckman H, Koedam N (2011) Successive cambia: a developmental oddity or an adaptive structure? PLoS ONE 6:e16558. https://doi.org/10.1371/journal.pone.0016558

Rowe N, Speck T (2005) Plant growth forms: an ecological and evolutionary perspective. New Phytol 166:61-72. https://doi.org/10.1 111/j.1469-8137.2004.01309.x
Růžička K, Ursache R, Hejátko J, Helariutta Y (2015) Xylem development-from the cradle to the grave. New Phytol 207:519-535. https://doi.org/10.1111/nph.13383

Ruzin SE (1999) Plant microtechnique and microscopy. Oxford University Press. Inc., New York

Schmitz N, Robert EM, Verheyden A, Kairo JG, Beeckman H, Koedam $\mathrm{N}$ (2008) A patchy growth via successive and simultaneous cambia: key to success of the most widespread mangrove species Avicennia marina? Ann Bot 101:49-58. https://doi.org/10.1093/ aob/mcm 280

Schweingruber FH, Börner A, Schulze E-D (2008) Atlas of woody plant stems. Evolution, structure, and environmental modifications. Springer, Berlin

Soh WY (1972) Early ontogeny of vascular cambium. I. Ginkgo biloba. Bot Mag Tokyo 85:111-124. https://doi.org/10.1007/BF02489508

Spicer R, Groover A (2010) Evolution of development of vascular cambia and secondary growth. New Phytol 186:577-592. https://doi. org/10.1111/j.1469-8137.2010.03236.x

Studholme WP, Philipson WR (1966) Woods with included phloem: Heimerliodendron runonianum and Avicennia resinifera. New Zeal J Bot 4:355-365. https://doi.org/10.1080/00288 25X.1966.10429054

Tamaio N, Vieira RC, Angyalossy V (2009) Origin of successive cambia on stem in three species of Menispermaceae. Revista Brasil Bot 32:839-848. https://doi.org/10.1590/S0100-8404200900 0400021

Terrazas T, Aguilar-Rodríguez S, Ojanguren CT (2011) Development of successive cambia, cambial activity, and their relationship to physiological traits in Ipomoea arborescens (Convolvulaceae) seedlings. Am J Bot 98:765-774. https://doi.org/10.3732/ ajb.1000182

Publisher's Note Springer Nature remains neutral with regard to jurisdictional claims in published maps and institutional affiliations. 